Jurnal Islamika: Jurnal Ilmu-Ilmu Keislaman

p-ISSN:1693-8712 | e-ISSN: 2502-7565

Vol. 18, No. 02, Desember 2018, pp. 93-100

\title{
MANAJEMEN KEPALA SEKOLAH DALAM MENINGKATKAN MUTU PENDIDIKAN
}

\author{
Ulil Azmi ${ }^{1}$, Muhammad Ridha DS ${ }^{2}$ \\ ${ }^{1}$ STAI Al-Hikmah Pariangan \\ ${ }^{2}$ Institut Agama Islam Negeri (LAIN) Kerinci \\ email: ulilazmi@staialhikmahpariangan.ac.id
}

\begin{abstract}
This study aims to explore and analyze the principal's management in improving the quality of education at MAS Thawalib Tanjung Limau. The approach used in this research is qualitative research approach by using field research type (field research). The subject of the study was the principal at MAS Thawalib Tanjung Limau. Data collection is done through observation, interview and documentation study. The analyst technique used is as follows: (1). Data reduction, (2). Presentation of data, (3). After the data is compiled and then drawn conclusions in the form of matrices and narratives. The results show that with good management, there is a quality improvement in MAS Thawalib Tanjung Limau, this is proven, with many events that have been successfully implemented in order to improve the quality, such as camps and provincial and provincial silat martial arts ever held at MAS Thawalib Tanjung Limau.
\end{abstract}

Keyword: Management, Heas Master and MAS Thawalib Tanjung Limau

\begin{abstract}
Abstrak: Penelitian ini bertujuan untuk menggali dan menganalisa manajemen kepala sekolah dalam meningkatkan mutu pendidikan di MAS Thawalib Tanjung Limau. Pendekatan yang digunakan dalam penelitian ini yaitu pendekatan penelitian kualitatif dengan menggunakan jenis penelitian lapangan (field research). Subyek penelitian adalah kepala sekolah pada MAS Thawalib Tanjung Limau. Pengumpulan data dilakukan melalui pengamatan, wawancara dan studi dokumentasi. Teknik analis yang digunakan adalah sebagai berikut: (1). Reduksi data, (2). Penyajian data, (3). Setelah data disusun kemudian ditarik kesimpulan dalam bentuk matrik dan narasi. Hasil penelitian menunjukkan bahwa dengan manajemen yang baik, terdapat peningkatan mutu di MAS Thawalib Tanjung Limau, hal ini terbukti, dengan banyaknya acara yang telah sukses dilaksanakan dalam rangka peningkatan mutu, seperti perkemahan dan perlombaat silat tingkat Provinsi dan Nasional yang pernah diadakan di MAS Thawalib Tanjung Limau.
\end{abstract}

Kata Kunci: Manajemen, kepala sekolah dan MAS Thawalib Tanjung Limau 


\section{PENDAHULUAN}

Pemerintah Indonesia telah menetapkan Peraturan melalui Menteri Pendidikan Nasional Republik Indonesia Nomor 13 Tahun 2007 Tentang Standar kepala sekolah/madrasah. Menciptakan kepala sekolah yang bermutu, merupakan salah satu program pemerintah dalam mengelola lembaga pendidikan di Indonesia yaitu dalam menghadapi tuntutan peningkatan mutu. masalah mutu banyak persoalan terkait dengan standar dan pengukuran mutu itu sendiri, untuk itu kepala sekolah harus memiliki konsep manajemen mutu yang handal dalam mengelola pendidikan yang bermutu.

Agama Islam juga menuntut manusia untuk melakukan perubahan ke arah yang bermutu ketika melakukan sesuatu kegiatan. Hal ini sesuai dengan firman Allah dalam Surat Al-Ra'du Ayat 11:

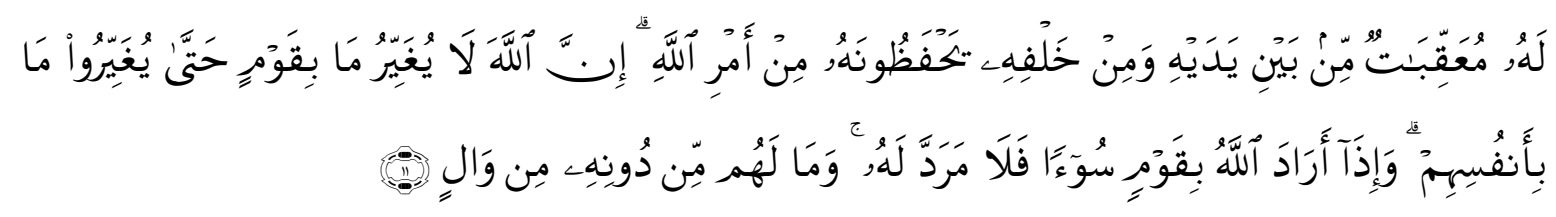

"Bagi manusia ada malaikat-malaikat yang selalu mengikutinya bergiliran, di muka dan di belakangnya, mereka menjaganya atas perintah Allah. Sesunggubnya Allah tidak merobah keadaan sesuatu kaum sehingga mereka merobah keadaan yang ada pada diri mereka sendiri. Dan apabila Allab menghendaki keburukan terhadap sesuatu kaum, maka tak ada yang dapat menolaknya; dan sekali-kali tak ada pelindung bagi mereka selain Dia.

Menurut Oemar Hamalik, pengertian mutu dapat dilihat dari dua sisi, yaitu segi normatif dan segi deskriptif. Dalam sisi normatif, mutu ditentukan berdasarkan pertimbangan (kriteria) intrinsik dan ekstrinsik. Berdasarkan kritria intrisik, mutu pendidikan merupakan produk pendidikan yakni manusia yang terdidik sesuai dengan standar ideal. Berdasarkan kriteria ekstrinsik, pendidikan merupakan instrumen untuk mendidik, tenaga kerja yang terlatih. Dalam artian deskriptif, mutu ditentukan berdasarkan keadaan hasil tes prestasi belajar. ${ }^{1}$

\footnotetext{
${ }^{1}$ Dzaujak Ahmad, 1996, Penunjuk Peningkatan Mutu pendidikan di sekolah Dasar, Jakarta: Depdikbud. hlm.
} 8. 
Manajemen peningkatan mutu pendidikan di sekolah adalah suatu metode peningkatan mutu yang bertumpu pada pendidikan di sekolah itu sendiri, mengaplikasikan sekumpulan teknik, mendasarkan pada ketersediaan data kuantitatif \& kualitatif, dan pemberdayaan semua komponen sekolah untuk secara berkesinambungan meningkatkan kapasitas dan kemampuan organisasi sekolah guna memenuhi kebutuhan peserta didik dan masyarakat.

MAS Thawalib Tanjung Limau sudah mengalami perubahan ke arah yang positif dalam meningkatkan mutu sekolah. Hal ini dibuktikan dengan banyaknya program-program keagamaan yang sudah terealisasi. Pembuktian tersebut sangat jauh berbeda dengan 5 tahun ke belakang. Adapun program yang sudah terealisasi adalah perkemahan pramuka antar pesantren di pulau Sumatera yang meliputi wilayah Sumatera Barat, Riau dan Jambi, yang dilaksanakan di MAS Thawalib Tanjung Limau. Hal ini belum pernah dilakukan sebelumnya guna untuk mendukung kurikulum 2013 yang mewajibkan kegiatan pramuka bagi peserta didiknya, kaligrafi, silat dan drumband.

Dalam menyeleksi guru, kepala sekolah menerima guru di MAS Thawalib Tanjung Limau sesuai dengan kompetensinya, bukan sekedar hanya memenuhi kuota jam pembelajarannya saja sebagai syarat untuk menerima tunjangan sertifikasi guru, kondisi tersebut berbeda dengan beberapa tahun yang silam.

\section{METODE}

Penelitian ini termasuk dalam kategori penelitian lapangan (field research). Peneliti menggunakan pendekatan penelitian kualitatif yang mana dapat menghasilkan penemuanpenemuan yang tidak dapat dicapai dengan menggunakan prosedur-prosedur statistik atau dengan cara kuantifikasi lainnya. Melalui penelitian kualitatif peneliti dapat mengenali subjek dan merasakan apa yang mereka alami dalam kehidupan sehari-hari, khususnya mengenai manajemen kepala sekolah dalam upaya meningkatkan mutu pendidikan di MAS Thawalib Tanjung Limau. Teknik analis yang digunakan adalah sebagai berikut: 1) reduksi data, dalam penelitian ini dilakukan dengan cara pemilihan, pengeditan, pemusatan perhatian pada penyederhanaan, pengabstrakan dan transformasi (pemindahan) data "kasar" yang muncul dari catatan tertulis di lapangan. Proses ini berlangsung secara kontinu (terus menerus) selama penelitian; 2) penyajian data, data yang telah disederhanakan disajikan dalam bentuk tulisan, teks naratif yang masih menggambarkan pengertian umum dari apa yang didapati di lapangan; 3) setelah data disusun, kemudian ditarik kesimpulan dalam bentuk matrik dan narasi. Selanjutnya peneliti menarik kesimpulan yang pada dasarnya merupakan gambaran secara 
komprehensif dan utuh dari informasi atau data yang diperoleh. ${ }^{2}$

\section{HASIL PENELITIAN DAN PEMBAHASAN}

Manajemen kepala sekolah dalam membuat perencanaan untuk meningkatkan mutu pendidikan di MAS Thawalib Tanjung Liman

Perencanaan kerja sekolah disusun oleh tim pengembang sekolah, menyusun Visi, Misi dan Tujuan sekolah berdasarkan profil sekolah yaitu: komponen pembelajaran dan kurikulum, komponen kesiswaan, komponen ketenagaan, komponen sarana dan prasarana, komponen pembiayaan, komponen peran serta masyarakat dan komponen pelayanan khusus. Rencana kerja sekolah disusun untuk program kerja setahun dan program kerja empat tahun, Program kerja tersebut memuat rencana pengembangan kurikulum dan pembelajaran, rencana pengembangan pendidik dan tenaga kependidikan, rencana pengembangan sarana dan prasarana, keuangan dan pembiayaan, rencana pengembangan kesiswaan, rencana pengembangan budaya dan lingkungan sekolah, rencana pengembangan peran serta masyarakat dan kemitraan, serta rencana-rencana kerja lain yang mengarah pada peningkatan mutu pendidikan.

Manajemen kepala sekolah dalam pengorganisasian untuk meningkatkan mutu pendidikan di MAS Thawalib Tanjung Limau

Pengorganisasian tata kelola fungsi dan tugas para guru dan karyawan tersesun dengan sistematis. Pengorganisasian tata letak guru mengenai pembagian tugas para guru dan karyawan sekolah di MAS Tahawalib Tanjung Limau belum terorganisir dengan baik karena ada 1 orang guru yang mengajarkan mata pelajaran yang tidak sesuai dengan latar belakang pendidikannya.

Manajemen kepala sekolah dalam pelaksanan untuk meningkatkan mutu pendidikan di MAS Thawalib Tanjung Limau

Pelaksanaan program peningkatan mutu pendidikan. Sekolah menyusun Kurikulum Tingkat Satuan Pendidikan, yang memuat struktur kurikulum, kriteria ketuntasan minimal, dan kalender pendidikan. Guru melaksanakan kegiatan pembelajaran sesuai dengan jadwal program tahunan, program semester dan melaksanakan pembelajaran sesuai dengan silabus dan Rencana Pelaksanaan Pembelajaran. Hasil observasi di sekolah masih ada guru belum

\footnotetext{
${ }^{2}$ Milles, M.B. and Huberman, M.A. 1984, Qualitative Data Analysis. London: Sage Publication., hlm. 133.
} 
dapat melaksanakan tugas secara optimal karena keterbatasan kompetensi guru dan keterbatasan sarana dan prasarana dan dana yang tersedia di sekolah. Peningkatan kompetensi guru perlu dilaksanakan melalui kegiatan KKG mini di sekolah dan KKG gugus sekolah yang dipandu oleh pemandu mata pelajaran, Hasil observasi tidak semua guru hadir pada hari pertemuan bahkan ada yang datang secara bergantian. Pengelolaan keuangan sesuai dengan RKAS, dan pertanggungjawaban keuangan dilakukan secara berkala. Hasil observasi kebutuhan anggaran belum mencukupi untuk peningkatan mutu pendidikan.

\section{Manajemen kepala sekolah dalam pengawasan untuk meningkatkan mutu pendidikan di MAS Thawalib} Tanjung Limau

Pengawasan dalam peningkatan mutu meliputi: pemantauan, supervisi, evaluasi diri dan akreditasi. Kegiatan pemantauan, supervisi, evaluasi pembelajaran dan evaluasi diri sekolah dilakukan oleh kepala sekolah, komite sekolah, guru dan pengawas sekolah. Faktor pendukung peningkatan mutu pendidikan berdasarkan analisis hasil SWOT yang menjadi kekuatan adalah jumlah guru yang memadai, sarana dan prasaran sekolah memadai. Kepemimpinan kepala sekolah yang demokratis dan terbuka. Kepala sekolah menempatkan warga sekolah sebagai mitra kerja. Kepala sekolah memberikan kebebasan kepada guru dalam proses pembelajaran untuk menciptakan kreativitas dan inovasi dalam pembelajaran mulai dari perencanaan pembelajaran, proses pembelajaran sampai pada evaluasi pembelajaran.

\section{Hasil pendidikan yang bermutu di MAS Thawalib Tanjung Limau}

Hasil mutu pendidikan di MAS Thawalib Tanjung Limau adalah:

a. Standar isi yang diharapkan belum sepenuhnya terlaksanakan. Hal ini disebabkan oleh beberapa guru yang belum memiliki persiapan mengajar. Pengembangan kurikulum sudah memamfaatkan buku petunjuk dan menyesuaikan dengan kebudayaan lokal. Pengembangan kurikulum sudah melakukan proses kegiatan pengembangan diri seperti silat, pramuka dan marshing band dan memasukkan muatan lokal seperti pengembangan seni kaligrafi.

b. Standar prosesnya belum semua guru melakukan proses yang sesuai dengan bobot penilaian yang tercantum dalam pedoman standar proses kurikulum. Pengwasan prosesnya sudah terlaksana walaupun belum ditindak lanjuti secara maksimal.

c. Standar kompetensi kelulusan siswa sudah hampir sepenuhnya telaksanakan, hal ini dibuktikan dengan banyaknya kegiatan yang ada dalam mengembangkan bakat siswa, seperti kegiatan pramuka, silat, marshing band, dan seni kaligrafi. Dan juga setiap tahunnya, 
para siswa dibina untuk melanjutkan pendidikan selanjutnya, seperti pembinaan siwa yang mau melanjutkan kuliah ke Al-azhar Cairo Negara Mesir.

d. Standar pendidik dan tenaga pendidikan belum sepenuhnya terpenuhi, karena kepala sekolah masih diangkat oleh Yayasan dan belum memilki sertifikat jabatan, sedangkan tenaga keguruannya masih ada 1 orang guru yang mengajarkan mata pelajaran yang belum sesuai dengan latar belakang pendidikannya, kendati sudah memiliki pengalaman mengajar lebih dari 5 tahun dalam bidang studinya. Tenaga kependidikan memang sudah memilki kualifikasi pendidikan S1, tapi belum sesuai dengan latar belakang pendidikannya. Kepala labor sudah memiliki kemampuanya dan kualifikasi pendidikan yang relevan, walaupun tenaga labornya belum relevan antara kualifikasi pendidikan dengan tugasnya.

e. Standar sarana dan prasarana pendidikan yang ada, sudah hampir memadai, walaupun belum ada beberapa ruang yang belum dimilki, seperti ruang IPA dan ruang perpustakaan hanya berfungsi untuk penyimpanan buku saja. Dan beberapa peralatan lain yang belum dimiliki untuk menunjang lancarnya aktifitas pendidikan.

f. Standar pengelolaan belum terlaksana dengan maksimal, karena belum melibatkan unsur masyarakat dan belum melakukan sosialisasi kepada warga sekolah dengan intensif. Walaupun sudah dilakukan persiapan untuk akreditasi sekolah, tetapi belum maksimal. Karena mengenai sarana dan prasarana yang belum terorganisir dengan baik.

g. Standar pembiayaan sekolah dilakukan dengan transparan baik secara lisan dan tulisan dilaporkan kepada masyarakat, yayasan dan pemerintah. Sumber dana sekolah melalui, iuran bulanan, masyarakat, yayasan dan pemerintah, dan digunakan untuk kelancaran aktifitas sekolah.

h. Standar penilaian yang dilkukan oleh sekolah adalah dengan berusaha untuk menyesuaikan dengan standar nasional pendidikan, walaupun sebagian kecil guru belum mampu untuk melaksanakannya. Sekolah juga bukan penyelengara UN, karena secara administrasi belum layak untuk menyelengarakan UN, jadi sekolah mempunyai sekolah induk yaitu, MAN 2 Batusangkar. Hasil UN dan penerbitan ijazah dilaksanakan di MAN 2 Batusangkar.

\section{PENUTUP}

Manajemen kepala sekolah dalam membuat perencanaan untuk meningkatkan mutu pendidikan di MAS Thawalib Tanjung Limau adalah dengan mengadakan perencanaan kerja sekolah disusun oleh tim pengembang sekolah, menyusun Visi, Misi dan Tujuan sekolah. Manajemen kepala sekolah dalam pengorganisasian untuk meningkatkan mutu pendidikan di 
MAS Thawalib Tanjung Limau adalah dengan cara melaksankan pengorganisasian tata kelola fungsi dan tugas para guru dan karyawan tersesun dengan sistematis. Manajemen kepala sekolah dalam pelaksanan untuk meningkatkan mutu pendidikan di MAS Thawalib Tanjung Limau adalah dengan cara melaksanakan program peningkatan mutu pendidikan. Sekolah menyusun Kurikulum Tingkat Satuan Pendidikan, yang memuat struktur kurikulum, kriteria ketuntasan minimal, dan kalender pendidikan. Guru melaksanakan kegiatan pembelajaran sesuai dengan jadwal program tahunan, program semester dan melaksanakan pembelajaran sesuai dengan silabus dan rencana pelaksanaan pembelajaran. Manajemen kepala sekolah dalam pengawasan untuk meningkatkan mutu pendidikan di MAS Thawalib Tanjung Limau adalah dengan melakukan pengawasan dalam peningkatan mutu meliputi: pemantauan, supervisi, evaluasi diri dan akreditasi. Kegiatan pemantauan, supervisi, evaluasi pembelajaran dan evaluasi diri sekolah dilakukan oleh kepala sekolah, komite sekolah, guru dan pengawas sekolah.

Hasil pendidikan yang bermutu di MAS Thawalib Tanjung Limau adalah terdiri dari: (1). Standar isi yang diharapkan belum sepenuhnya terlaksanakan. (2). Standar prosesnya belum semua guru melakukan proses yang sesuai dengan bobot penilaian yang tercantum dalam pedoman standar proses kurikulum. (3). Standar kompetensi kelulusan siswa sudah hampir sepenuhnya telaksanakan. (4). Standar pendidik dan tenaga pendidikan belum sepenuhnya terpenuhi. (5). Standar sarana dan prasarana pendidikan yang ada, sudah hampir memadai. (6). Standar pengelolaan belum terlaksana dengan maksimal. (7). Standar pembiayaan sekolah dilakukan dengan transparan baik secara lisan dan tulisan. (8). Standar penilaian yang dilkukan oleh sekolah adalah dengan berusaha untuk menyesuaikan dengan standar nasional pendidikan.

\section{REFERENSI}

Departemen Pendidikan dan Kebudayaan RI, 1995, Kamus Besar Bahasa Indonesia, edisi kedua, Jakarta: Balai Pustaka.

Dzaujak Ahmad, 1996, Penunjuk Peningkatan Mutu pendidikan di sekolah Dasar, Jakarta: Depdikbud.

E. Mulyasa, 2005, Menjadi Kepala Sekolah Profesional, Bandung: PT. Remajda Rosda Karya.

Jerome S. Arcaro, 2007, Pendidikan Berbasis Mutu: Prinsip prinsip Perumusan dan Tata Langkah Penerapan, Yogyakarta: Pustaka Pelajar. 
M. Ngalim Purwanto, 1990, Psikologi Pendidikan, Bandung: PT. Remaja Rosdakarya.

Malayu S.P Hasibuan, 1990, Manajemen Dasar, Pengetian, Dan Masalah, Jakarta: CV. Haji Mas Agung.

Milles, M.B. and Huberman, M.A. 1984, Qualitative Data Analysis. London: Sage Publication.

Sutopo, Hendyat, et.al. 1982. Kepemimpinan dalam Pendidikan. Surabaya: Usaha Nasional.

Permen Diknas Republik Indonesia No. 13 Tahun 2007 tentang Standar Kepala Sekolah/Madrasah

Undang-undang Republik Indonesia, No. 20 Tahun 2003 tentang Sistem Pendidikan Nasional, Bandung: Citra Umbara.

Wahjosumidjo, 1999, Kepemimpinan Kepala Madrasah Tinjauan Teoritik dan Permasalahan, Jakarta: Raja Grafindo Persada. 